\title{
Willingness of students of professional education program to join non permanent employee (PTT)
}

\author{
Jenny Diana*, Asty Samiaty Setiawan*, Gilang Yubiliana* \\ *Department of Dental Public Health Faculty of Dentistry Universitas Padjadjaran
}

\begin{abstract}
Introduction: Placement policy of doctors and midwives with PTT system has been implemented since 1992 to address the distribution of doctors and dentists who have not been evenly distributed in Indonesia, but until now its spread is still far from expected. The ratio of doctors in Puskesmas for the region in western Indonesia is much higher than eastern Indonesia. The purpose of this study was to determine the willingness of dental professional education program student of Faculty of Dentistry in Padjadjaran University to be non permanentemployee (PTT). Methodes: This study was a descriptive study done by survey technique. The data obtained by questionnaires. Results: Dental students of professional education programs who were willing to be a non permanent employee (PTT) was $82 \%$ and those who were not willing was $18 \%$. Conclusion: The dental students of professional education programs mostly willing to be a non permanent employee.
\end{abstract}

Keywords: Willingness, students of Professional Program, PTT.

\section{INTRODUCTION}

Indonesian health statute no. 36 clause 5 in 2009 state that everyone has the same right to gain access of health resources and to acquire a safe, quality and affordable health services. This condition has not been well realized, since the number of dentists in Indonesia are still far from the target.

Indonesia Sehat 2010 vision indicator by Ministry of Health Republic of Indonesia reported that the ratio of dentists per total population is 11:100.000 or 1 dentist for 9091 population. The number of Indonesian population in 2010 by the Central Bureau of Statistics was 237.556.363. It means that the number of dentists required in Indonesia is 26.130 , whereas according to data from KKI, only 22.237 dentists were registered until December 2010. In conclusion, the ratio of dentists pertotal population in Indonesia now is 9:100.000.

A study report on policy planning of healthcare worker Directorate Nutrition and Public Health Deputy of Human Resources and Culture Bappenas 2005 state that the number of healthcare worker in Indonesia especially dentists compared to other countries in the last ten year is stilllo The ratio of dentists per 100.000 population in Indonesia is still 2,07 far below Australia $(40,0)$; Austria $(47,2)$ :Finlandia( $(93,7)$; Japan $(68,8)$; Malaysia $(8,6)$; and Dutch $(47,1) .{ }^{1}$ The number of doctors and dentists practicing is still inaccurate until now, as the consequence, educational institutions can not predict the number of graduate 
doctors and dentists they should yield. Doctor and dentist practices are also not evenly distributed, this is due to their tendency to practice in a big town. ${ }^{2}$

Assignment policy of doctor and midwife by non permanent health care worker system (PTT) has been implemented since 1992 to overcome the uneven distribution of doctors and dentists in Indonesia, however, until now the distribution is still far from expected. National Health System reports the ratio of doctors to puskesmas for the Western Indonesia region is much higher than the eastern part of Indonesia. The ratio of physicians to puskesmas in North Sumatra is 0.84 compared toEastNusaTenggaraprovince 0.26 and province of Papua 0.12. ${ }^{3}$

Data from the Ministry of Health in 2005 showed that dentists' needs in each province were not comparable with the number of dentists applying for PTT. West Sumatra Province requires 56 dentists, while those who register only 15 dentists. DKI Jakarta has closed the registration for PTT, while the dentists who register there are 90 dentists. ${ }^{4}$

Professional Standards of Dentistry mention that dental profession education is academic education and professional education directed to mastery and application of science to society in the field of dentistry. ${ }^{2}$ Students of professional education program is expected to have an idea about Non Permanent Employee since they will complete dental profession education program. Based on the above data, this study was conducted to find out how much the willingness of students of professional education program Faculty of Dentistry Padjadjaran University to become NonPermanent Employee. The purpose of this research is to know the willingness of students of professional education program Faculty of Dentistry Padjadjaran University become Non Permanent Employee.

\section{METHODS}

The research method used in this research is descriptive research method with survey technique. The objective is to provide a description or describe of a situation objectively and make an assessment of the implementation of a program in the present, then the result is used to plan theimprovement of the program. ${ }^{5}$

The population of this study are all students of professional education program Faculty of Dentistry Padjadjaran University, 478 students in total, with population criteria are students who have passed the first semester in the professional education program at the Faculty of Dentistry Padjadjaran University and willing to fill out the questionnaire.

\section{RESULTS}

Respondent's answer about willingness to join PTT after graduate as a dentist can be seen in Figure 1.

The result showed that out of 164 respondents, $2 \%$ were willing (135 respondents) and the $18 \%$ were not willing(29 respondents). Respondents' answer regarding the reasons for willing to become Non Permanent Employee can be seen in figure 2 .

Results showed the willing respondents reasons to become non permanent employee worker: $58 \%$ (78 respondents) is to add experiences, $24 \%$ (32 respondents) because of financial reason, $10 \%$ (13 respondents) as a dedication, $7 \%$ (10 respondents) as an advantage to be CPNS, $1 \%$ ( 2 respondents)answeredothers.

The answers of respondents who were willing to become Non-Permanent Employee on the criteriaof choice of region scan be seen in Figure 3.

The above diagram showed 46\% $\quad 62$ respondents) chose remote area, $31 \% \quad(42$

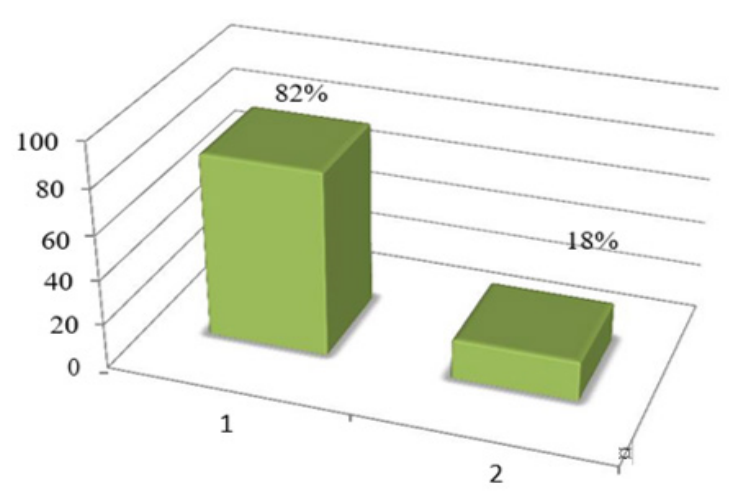

Note: (1) Willing; (2) Unwilling

Gambar1. Student of Professional Education Program FKG UNPAD willingness as non permanent pemployee 


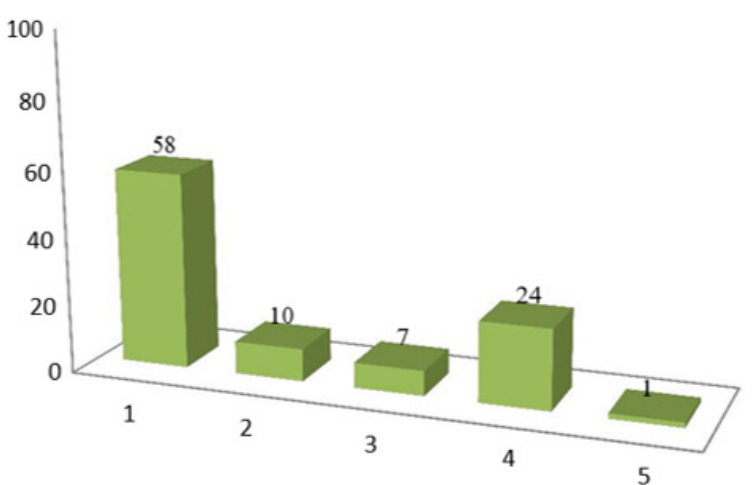

Notes:(1) Experience; (2) Dedication; (3) CPNS advantage; (4) Finance;(5) Others

Figure 2. Reasons of student of FKG UNPAD professional education program who are willing to become Non Permanent Employee

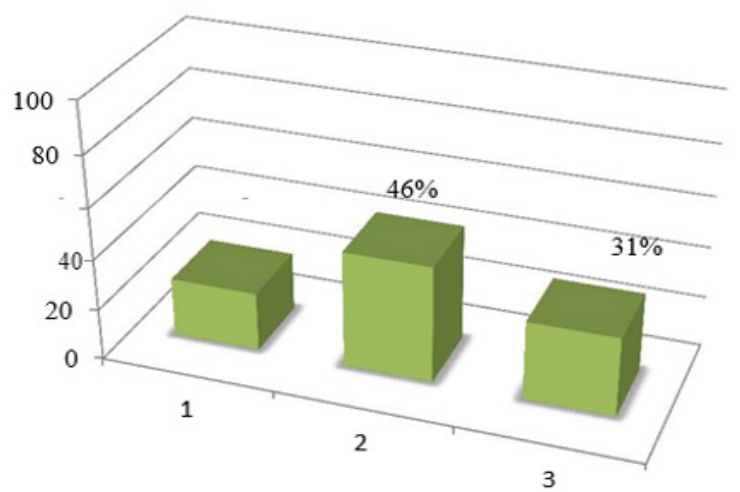

Notes: (1) Common; (2) Remote; (3) Very Remote

Figure 3. Criteria of choice of regions by student of professionaleducation program FKG Unpad who are willing to becomen on permanen temployee.

respondents) chose very remote area, and $23 \%$ (31 responden chose common area as their PTT region destination. Reasons for the respondents who selected the area criteria for which the PTT is seen in Figures 4,5 and 6.

Diagram in figure 4 showed reason of respondent in choosing remote area criteria: $29 \%$ (18 respondents) was to add experience, 16\% (10 respondents) gave no answer, $13 \%$ (8 respondents) was because of easier accessibility, $13 \% \quad(8$ respondents) for financial, 10\% (6 respondents) because of relative brief period of time, $8 \%$ ( 5 respondents) as a dedication, $5 \%$ ( 3 respondents) for security reason, $3 \%$ ( 2 respondents) for family reason, $2 \%$ (1 respondent) for the tourism, 1\% (1 responden)forcapability reason.

The above diagram (figure 5)showed the reason of the respondents to choose the criteria

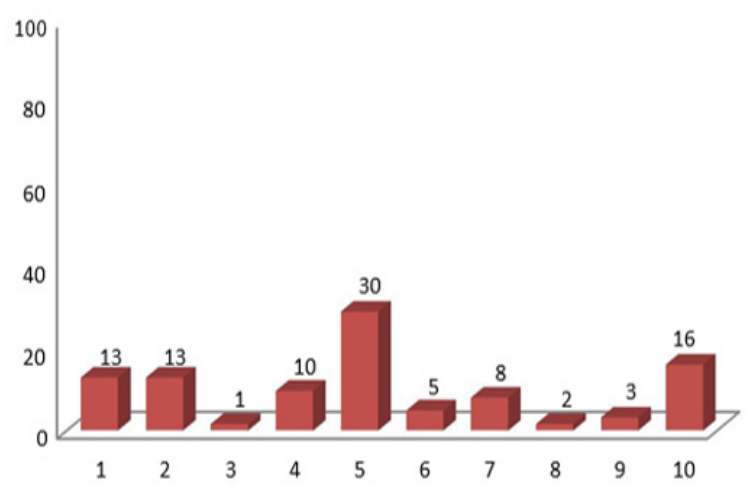

Notes: (1) Access; (2) Finance; (3) Capability; (4) Time; (5) Experience; (6) Security; (7) Dedication; (8) Tourism; (9) Family; (10) No answer

Figure4. Reason of respondent choosing remote area criteria

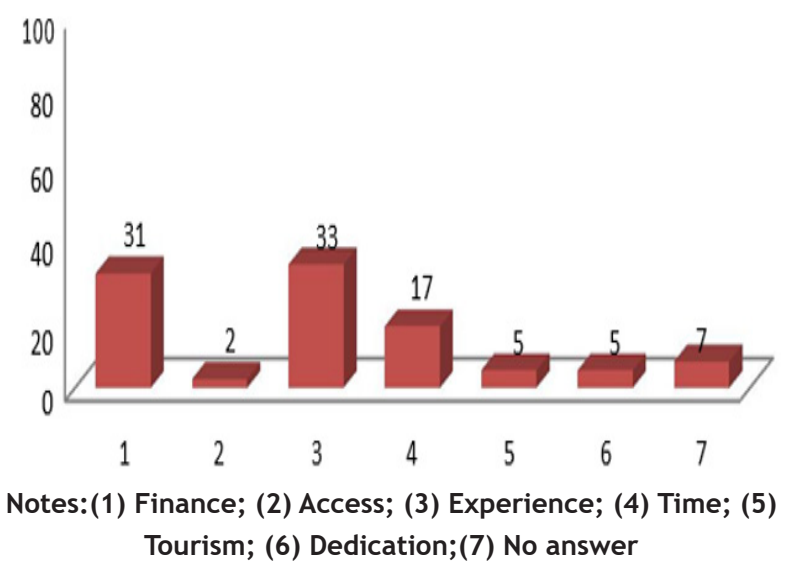

Figure 5. Reasons of respondents in choosing criteria of very remote area

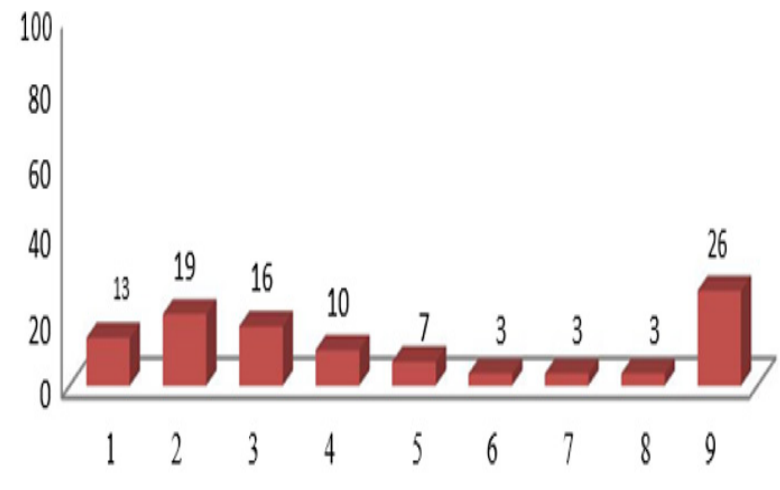

Notes: (1) Tools; (2) Access; (3)Family; (4) Culture daptation; (5) Dedication;(6) Trying something new;(7) Experience;(8) Others;(9) No anwer

Figure 6. Reason of respondent in choosing common area criteria

of very remote area is $33 \%$ (14 respondents) with reason to add experience, $31 \%$ (13 respondents) for financial reasons, $17 \%$ (7 respondents) for a 
faster time, 7\% (3 respondents) for no reason, 5\% ( 2 respondents) for dedication, 5\% (2 respondents) answered for tourism area, 2\% (1 respondent) for easyaccess. The diagram in figure 6 showed respondent's reasons in choosing common area criteria. 26\% (8 respondents) gave no reason, $19 \%$ (6 respondents) answered for easier access, $16 \%$ (5 respondents) for family reason, 13\% (4 respondents) for suffice tools, 10\% (3 respondents) for easier culture adaptation. 7\% (2 respondents) for dedication, 3\%(1 respondent) answere do thers. Respondents'answers regarding the their area of estination can be seen in figure 7 .

Based on the above diagram, 46\% $(62$ respondents) were willing to join PTT in Central Indonesia which includes Kalimantan, Sulawesi, Nusa Tenggara, and Bali. 33\% (44 respondents)

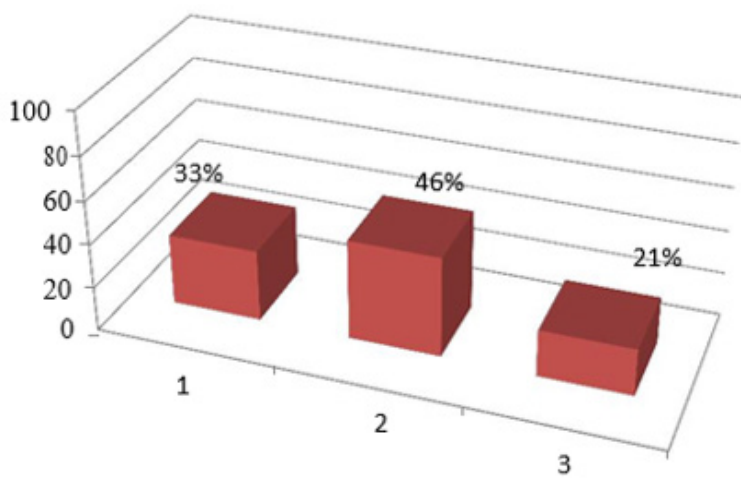

Notes:(1) West Indonesia; (2) Central Indonesia; (3)East Indonesia

Figure 7. Area of choice by FKG UNPAD Professional Education Program Students who were willing to join as non permanent employee

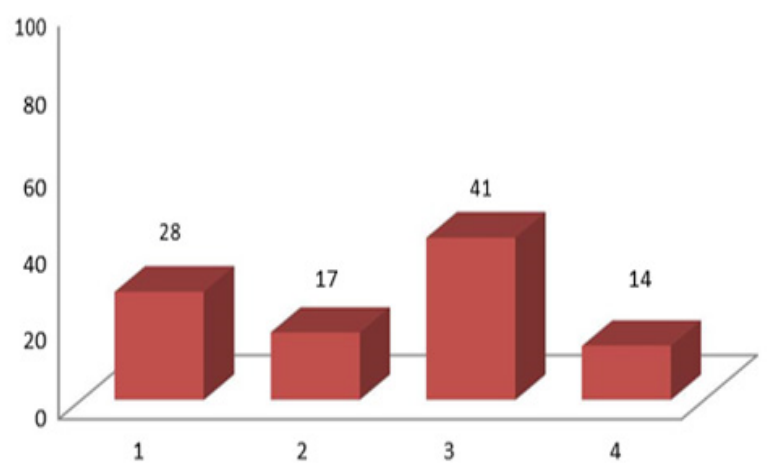

Notes: (1) Not allowed by the family; (2) Difficult access to public facilities; (3) Intention of continuingeducation/take specialization;(4)Others.

Figure8. Reasons of FKG Unpad professional education programstudent who were not willing to join non permanen temployee chose West Indonesia which includes Sumatra and Jawa. 21 \% (29 respondents) chose East Indonesia which includes Maluku and Papua.

continuingeducation/takespecialization;(4)

thers Based on the above diagram, 41\% (12 respondents) respondents who were not willing to join as non permanent employee were intended to continue their education or specialization, $28 \%$ ( 8 respondents) were not allowed by the family, $17 \%$ (5 respondents) mentioned of access to public facilities is difficult, and 14\% (4 respondents) answered others opening practice and intended to open theirown business which is not related to dentistry.

\section{DISCUSSION}

Respondents who were willing to become Non-Permanent Employee after graduating as a dentist were $82 \%$ (135 respondents) and those who were not willing were $18 \%$ ( 29 respondents). Majority of respondents were willing to become Non Permanent Employee supported by respondents' understanding of definition of non permanent Employee (96\%). Non Permanent Employee under the Decree of the Minister of Health No. 1540 of 2002 is an officer appointed by a competent authority for a certain period of time to carry out administrative and professional administrative and administrative duties on health care facilities and is not domiciled as a civil servant. ${ }^{6}$

Most of the respondents remained willing to join as Non Permanent Employee despite knowing the fact that PTT is not obligatory for graduate doctors and dentists. This policy was enacted since 2007 pursuant to Minister of Health Decree no. 512 / MENKES / PER / IV / 2007 which does not have a certificate that has completed PTT as a condition to obtain the License of Practice (SIP) $(\mathrm{MOH}, 2007)$. The majority of respondents willing to become Non-Permanent Employee will support the achievement of one of the objectives of the National Health System subsystem which has a fair, equitable, affordable and quality healthcare program to ensure the implementation of health development in order to improve the highest levelof public health. ${ }^{7}$ Minister of Health Decree No. 004 / Menkes / SK / 2003 on policy and decentralization in the health sector stated that in establishing health human resource management 
system it is necessary to improve and consolidate the planning, procurement of health manpower, utilization, and empowerment of health profession. One of the steps to strengthen the human resource management system is through the empowerment of human resources including the development of heal them powerment models for remote areas. $^{8}$

In 2010 the Ministry of Health implemented a program known as internship program. This program has the same goal with PTT is the distribution of healthcare workers. The internship program is a process of strengthening the quality of the physician profession to apply the competencies gained during education, in an integrated, comprehensive, independent manner and using the family medical approach in order to develop and align the results of education by field practice. $^{9}$

Respondents who are willing to become Non Permanent Employee out of the majority (58\%) provide reasons to add experience, as well as financial reasons, dedication, for added value as CPNS, and others. According to Herzberg's theory that one that affects a person in his task or job is a factor causing satisfaction or motivational factors that include achievement, reward, responsibility, opportunity to advance and the work itself (Notoadmodjo, 2007) .5 Ministry of Health Decree No.1540 2002 article 28 a states that medical personnel as Non-Permanent Employee earn income in the form of basic salary, Non-Permanent Employee allowance, allowances for those located in remote and remote areas, income tax benefits and incentives. Reasons to add value as CPNS in accordance with the Minister of Health Decree No. 1540 year 2002 article 29 point j: medical personnel as Non Permanent Employee placed in remote / very remote area is given bonus value at the time of selection of acceptance of CPNS and Presidential Decree no. 37 years 1991 point 2b, the priority of appointment as civil servants. ${ }^{10}$

PTT consists of PTT in central and PTT in region. This type of PTT is listed in Article 6 of Minister of Health Decree No. 1540 of 2002 that Non-Permanent Employee include Non-Permanent Employees in central and Non-Permanent Employees of provincial / district / municipal areas (MOH, 2002) .6 Non-Permanent Employees relate to regional autonomy underway with the enactment of Law no. 22/1999 and Law no. $25 / 1999$. This law implies that the district or municipal governments have autonomy in managing the financial or scientific resources (including facilities and infrastructure investments) most urgently to upgrade skills and empower human resources. One of the existing resources in the community is health workers who are prepared to establish health services for local communities. ${ }^{6}$

Respondents who were willing to join PTT majority chose remote areas (46\%), followed by very remote areas (31\%), and a small proportion chose regular areas (23\%). Criteria for destination areas of PTT consist of common, remote, and very remote areas. This is in accordance with articles 12 and 21 of the Minister of Health Decree No. 1540 of 2002 which states that the appointment of medical personnel as non-permanent Central and Provincial/District/Municipal Officers may be conducted in remote, very remote and common areas. $^{6}$

Respondents who chose remote areas gave reasons to add experience (29\%), respondents believed that working in remote areas would find many new experiences, especially those related to the respondent's profession. The next reason is easy access. Remote areas according to Minister of Health Decree No. 1540 in 2002 is difficult to reach due to various reasons such as geography (mountainous islands, land, forests and swamps). ${ }^{6}$ Minister of Health Regulation No. 949 of 2007 states that the criteria of remote areas such as public transportation used are (land /air/air) routine up to twice a week. ${ }^{11}$

Respondents who chose the very remote areas (33\%) gave reasons to add experience, $31 \%$ for financial reasons. This is because income in very remote areas is greater than usual remote areas. $^{12} 17 \%$ answered because of faster time, although now there is a new policy where the service time for remote and very remote areas is the same in one year $(\mathrm{MOH}, 2011) .13 \mathrm{~A}$ total of $7 \%$ did not give a reason, $5 \%$ answered the reason for devotion, $5 \%$ replied to the tourist area, $2 \%$ answered the reason for easy access. Very remote area according to Minister of Health Decree No. 1540 of 2002 is a very difficult area to reach due to various reasons such as geography (mountainous islands, terrestrial, forest, and swamp). ${ }^{10}$ The criteria of remote areas according to Minister 
of Health Regulation 949 of 2007 are the area in which public transportation used in the form of land (air/water/air) routine up to one time a week, travel time takes more than 8 (eight) hours travel time, located in the border areas of other countries, both land and the outer islands. ${ }^{11}$

Majority of respondents did not give reasons for choosing a regular area, this could be because the respondent did not know much about PTT, because before forming the right attitude there should be efforts to provide appropriate knowledge. Knowledge will stimulate psychophysical dynamics such as needs, motives, feelings, concerns and decision-making within the individual. ${ }^{14}$ The next reason for choosing common areas is easier access, family, adequate means, adaptable to new areas, for devotion, and others.

The majorities of respondents who are willing to join PTT (46\%) choose to work in the middle of Indonesia include Kalimantan, Sulawesi, Nusa Tenggara, and Bali. Observations conducted by researchers suggested that respondents prefer the central part of Indonesia because according to the assumption that the respondents of central Indonesia are not too isolated, also not classified as common area criteria. The difference between western Indonesia and eastern Indonesia is also quite remote, $33 \%$ choosing western part of Indonesia to cover Sumatra and Java, 21\% choose eastern Indonesia covering Maluku and Papua. This is in line with data from the Ministry of Health regarding the distribution and ratio of health workers which indicates a disparity between Puskesmas in western Indonesia and eastern Indonesia. ${ }^{7}$

The results showed that respondents who were not willing to become Non Permanent Employees as much as $18 \%$. The reason for the unavailability of respondents was that $41 \%$ wanted to continue their education or specialization, $28 \%$ were not allowed by the family, $17 \%$ access to public facilities was difficult, and $14 \%$ answered others (wanted to start a career in the city and did not want to practice). High interest to continue specialization is expected to overcome the number of unequal specialist personnel in Indonesia. In 2008 DKI Jakarta had 2890 specialists (23.92\%), East Java 1980 (16.39\%), West Java 1881 (15.57\%), while in West Sumatra only $167(1.38 \%)$. The disparities in the dissemination of these specialists are unfair, especially in the context of national policies that use full payments for the poor. The poor will find it difficult to get access to medical services in rare areas of specialist doctors, whereas in the case that many specialists will be very easy. Consequently, central funding for the poor is feared to be used more in big cities and in Java. ${ }^{15}$

Socialization on Non Permanent Employee Program is expected to increase the interest of fresh graduates dentist to join PTT, in order to overcome the distribution problem of dentist which is not evenly distributed in Indonesia.

\section{CONCLUSION}

Students of professional education program mostly willing to become Non Permanent Employee.

\section{REFERENCES}

1. Bappenas. Kajian kebijakan perencanaan tenaga kesehatan. Jakarta: 2005.

2. KKI. Rencana strategis konsil kedokteran Indonesia 2005-2010. Jakarta: 2006.

3. Depkes. Kebijakan Kesehatan Gigi dan Mulut. Jakarta: Direktorat Jenderal Bina Pelayanan Medik. 2009. p. 15.

4. Depkes. Rekapitulasi Daftar Antrian dan Kebutuhan Dokter Gigi Bulan Februari untuk Pengangkatan Bulan April 2005. Available from:www.depkes.go.id. [Cited 16 Nov 2010]. 2010.

5. Notoadmojo. Metodologi Penelitian Kesehatan. Jakarta: Rineka Cipta. 2010. p. 35,124.

6. Depkes. Keputusan Menteri Kesehatan Republik Indonesia Nomor 1540/Menkes/SK/ XII/2002/Tentang Penempatan Tenaga Medis Melalui Masa Bakti dan Cara Lain. 2002.

7. Depkes. Sistem Kesehatan Nasional. Jakarta: 2009.

8. Budiarto. Pengembangan Model Rekruitmen dan Pendayagunaan Tenaga Keperawatan di Daerah terpencil. Available from:www. litbang.depkes.go.id/. [Cited 22 April 2011].

9. Depkes. Program Internsip Dokter Indonesia Dilaksanakan Di 11 Fakultas Kedokteran. Available from:www.depkes.go.id. [Cited 14 Jul 2011]. 2011. 
10. Depkes. Beberapa model pendayagunaan tenaga kesehatan non-PNS dalam Otonomi Daerah. Jakarta: Badan Pengembangan dan PemberdayaanSumberDayaManusia.2002.p.1.

11. Depkes. Peraturan Menteri Kesehatan Republik Indonesia Nomor 949/MENKES/PER/VII/2007 Tentang Kriteria Sarana Pelayanan Kesehatan Terpencil Dan Sangat Terpencil. 2007.

12. Depkes. 2008. Kebijakan Departemen Kesehatan Tentang Pengadaan Dokter PTT. Jakarta: Biro Kepegawaian Setjen Departemen Kesehatan. Available from: www.cdc.fk.ui. ac.id. [Cited 14 Nov 2010].
13. Depkes. Kemkes tempatkan 1080 Dokter PTT di Daerah Terpencil dan Sangat Terpencil. Available from:www.depkes.go.id.[Cited18 April 2011]. 2011.

14. Azwar S. Sikap Manusia Teori dan Pengukurannya. $2^{\text {th }}$ ed. Yogyakarta: Pustaka Pelajar. 2007.h. 30.

15. Trisnantoro, Handono. Inovasi dalam pemberian pelayanan berdasarkan kontrak di RS Cut nya'dien Kabupaten Aceh Barat Kalimantan Timur. Available from:http:// www.jmpk-online.net/. [Cited 22 Apr 2011].2008. 